\title{
Integrated management of multiple water sources for multiple uses: rural communities in Limpopo Province, South Africa
}

\author{
Barbara van Koppen ${ }^{1}$, Moritz Hofstetter ${ }^{1}$, A Edward Nesamvuni² and Quinex Chiluwe ${ }^{3}$ \\ 'International Water Management Institute, P Bag X813, Silverton 0127, South Africa \\ 2University of Venda, P.O. Box 6796, Thohoyandou 0950, South Africa \\ ${ }^{3}$ QRC Consulting, PostNet Suite 9, P/Bag X108, Centurion 0046, South Africa
}

This study fills a knowledge gap about low-income rural communities' holistic management of multiple water resources to meet their multiple needs through multiple- or single-use infrastructure. Six low-income rural villages in Limpopo Province were selected with a diversity in: service levels, surface and groundwater resources, public infrastructure (designed for either domestic uses or irrigation but multiple use in reality) and self-supply (people's individual or communal investments in infrastructure). Focusing on water-dependent livelihoods and water provision to homesteads, distant fields and other sites of use, three policy-relevant patterns were identified. First, most households have two or more sources of water to their homesteads as a vital buffer to irregular supplies and droughts. Second, infrastructure to homesteads is normally for domestic uses, livestock and, for many households, irrigation for consumption and sale. Public infrastructure to irrigate distant fields is multiple use. Exceptionally, self-supply point sources to distant fields are single use. Water bodies to other sites of use are normally multiple use. As for large-scale infrastructure, multiple-use infrastructure is cost-effective and water-efficient. Third, in four of the six villages people's self-supply is a more important water source to homesteads than public infrastructure. In all villages, water provided through self-supply is shared. Self-supply improves access to water faster, more cost-effectively and more sustainably than public services do. In line with international debates, self-supply is there to stay and can be supported as a cost-effective and sustainable complementary mode of service delivery. A last potential policy implication regards community-driven planning, design and construction of water infrastructure according to people's priorities. This may sustainably harness the above-mentioned advantages and, moreover, communities' ability to manage complex multiple sources, uses and multiple-use infrastructure, whether public or selfsupply, as a matter of daily life.

\section{CORRESPONDENCE}

Barbara van Koppen

EMAIL

b.vankoppen@cgiar.org

\section{DATES}

Received: 14 March 2018

Accepted: 11 November 2019

\section{KEYWORDS}

rural water services,

community-led, self supply

\section{COPYRIGHT}

() The Author(s)

Published under a Creative Commons Attribution 4.0 International Licence (CC BY 4.0)

\section{INTRODUCTION}

In spite of the water sector's policy commitments and resource allocation to develop and manage infrastructure that 'leaves no one behind', remarkably little is known about the ways in which those who are left behind currently use, develop and manage water and envisage incremental improvements, especially in rural areas where people with agriculture-based and diversified livelihoods depend in many ways on water. Policies are clear globally, for example in the Sustainable Development Goal (SDG) 1 (no poverty), SDG 2 (ending hunger) and SDG 6 (water). South Africa's Constitution commits to realizing everyone's rights to water and food and the government has invested significant public resources to address the pre-1994 infrastructure backlogs in lowincome areas. However, as elsewhere, results are disappointing. Nationally, over 3 million people still do not have access to a basic water supply service and 14.1 million people do not have access to safe sanitation. The reliability of services that have been provided since 1994 is declining, with only $64 \%$ of households having access to a reliable water supply service (Balzer, 2019). In rural Limpopo Province, Ramugondo et al. (undated) found that only $14 \%$ of water infrastructure implemented is fully functional, while $15 \%$ is sub-functional and $71 \%$ is dysfunctional. A better understanding of communities' practices, knowledge and priorities will not only ensure 'nothing about them without them' but may also open up new options for governments, development partners, NGOs, financers and academia to render public water infrastructure development in low- and middleincome settings more cost-effective and sustainable.

Two global streams of policy-relevant knowledge contribute to such better understanding: first, research on de facto multiple uses of public infrastructure and, second, on self-supply in the sense of peoples' own investments in small-scale water infrastructure construction, operation and maintenance, either as individual households (for individual self-supply) or as groups (for communal self-supply). Yet, this knowledge remains focused on one specific infrastructure and water source and not the community-scale context.

The first stream of knowledge challenges the strict sectoral divides of the public water sector in which publicly financed infrastructure is assumed to be exclusively used for the single use of their mandate: either drinking water (or, more correctly, domestic uses), or irrigation, or livestock. In reality, however, significant proportions of users also use public infrastructure informally for other purposes than the sector's mandate (Moriarty et al., 2004; Van Koppen et al., 2014). In rural South Africa, Perez de Mendiguren et al. (2004) and Naidoo et al. (2009) confirmed the same for rural 
water supplies designed for domestic uses. As any technical designer of large-scale infrastructure would attest, multipleuse infrastructure makes sense. At low incremental costs to infrastructure designed for a single use, high incremental benefits from other uses are achieved. The same principle applies for smaller scale infrastructure (Renwick et al., 2007). Policies in South Africa reflect this. The Strategic Framework for Water Services introduced the notion of 'climbing the water ladder' to enable such multiple uses once basic domestic needs are met (DWAF, 2003). This is echoed in the Draft Norms and Standards for Domestic Water Supply and Sanitation (DWS, 2018). Poor rural peoples' multiple water needs are also recognized in the National Water Resource Strategy 2 (DWA, 2013).

The second stream of knowledge identifies the wide prevalence of people's self-supply. Self-supply is informal and outside the ambit of the state. For a long time, research on self-supply has followed the same sectoral divides. Studies on farmer-managed irrigation schemes, mostly gravity based, have been conducted since the 1990s in Asia (Ostrom, 1992) and Africa (Adams et al., 1997). From the 1990s onward, booming individual groundwater pumping and water markets among adjacent farmers have been documented in Asia (Shah 2009) and then also for Africa (Shah, 2009; Giordano et al., 2012; Woodhouse et al., 2016). Similarly, in Limpopo Province, South Africa, remote sensing techniques identified at least 70000 ha of informal smallholder irrigation. This is 3 to 4 times as large as the total area of public smallholder irrigation schemes (Van Koppen et al., 2017). By now, the World Bank calls farmerled irrigation development 'a revolution already in progress' (World Bank, 2018).

In the water, sanitation and hygiene sector, the body of evidence of self-supply for domestic water uses is also growing (Sutton et al.,2012; Butterworth et al., 2013). Households or small groups who can afford to, invest in infrastructure. This water is often shared. In high-income countries, self-supply remains one of the options, especially in remote rural areas. Not surprisingly, research also starts showing how self-supply infrastructure is often multiple use. For example, new market opportunities for irrigated produce trigger investments in infrastructure that enables domestic uses as well, as found in Ethiopia (Sutton et al., 2012).

In both sectors, policy recommendations evolved for so-called 'supported self-supply'. They overlap: market-led supply chains of affordable technologies with after-sales services, technical training, financing facilities and developing produce markets. Technologies also overlap, ranging from buckets to mechanized pumps. The remaining difference regards the targeted site of use: whereas the WASH sector focuses on homesteads, the irrigation sector focuses on one or more assumingly isolated distant fields. Other sites of use, such as village dams or open surface water bodies, can be overlooked.

There is still a knowledge gap at community scale, where everyone has domestic water needs and many also have productive water needs. Here, people combine multiple water sources (rain, runoff, ponds, wetlands, soil moisture, groundwater) through a mix of individual or communal infrastructures that are publicly financed or self-financed. Qualitative participatory water resource mapping exercises have shown how communities can swiftly sketch the basic elements (SADC Danida, 2009). However, commenting on the outcomes of participatory resource mapping in Bushbuckridge, Cousins et al. (2007) dub the multiple pieces of functional and dysfunctional infrastructure for domestic uses and irrigation, layer over layer, as 'spaghetti'. This raises the question: is it possible to further develop quantitative and qualitative insights and to identify patterns in these communityscale complexities that rural people manage as a matter of daily life? Can this knowledge inform public support agencies and their engineering designs towards greater cost-effectiveness and sustainability? The study presented in this article explores answers to these questions.

The study aims to identify patterns in rural communities' development and management of multiple water sources to meet their multiple needs through multiple-use or single-use infrastructure in low-income rural South Africa, and to explore policy implications.

\section{METHODOLOGY}

\section{Conceptualisation}

Unlike sectoral approaches, the conceptualisation of the links between peoples' water-dependent livelihoods and water development and management needs to accommodate the use and reuse of multiple sources and multiple-use or single-use infrastructure, whether publicly financed or self-supply or combinations. This is done by focusing on the sites of water use and the labour or infrastructure used to bridge the distance between the source of water and the site of use in communities' spatial lay-out. Three sites of use are distinguished:

- The homestead including land around the house. If a water source for homestead uses is at a distance, one has to move the water to the homestead either through infrastructure or by labour (carrying containers, with wheelbarrows if the terrain allows, or in flat areas, by rolling, for example, $200 \mathrm{~L}$ drums, or by tankers).

- Distant field, which is not adjacent to the homestead, so unable to access water at homesteads.

- Other sites of water use, which are usually near a water source (open stream, pond, or dam). In this case, people or their livestock move to the water source.

Definitions of 'self-supply' or 'public infrastructure' are the ones mentioned above. Water provision to schools, clinics or other public venues is not explicitly considered.

\section{Village selection and method}

Six low-income rural villages were selected in two of the poorest districts (Sekhukhune and Vhembe District) of Limpopo Province, which is one of South Africa's poorest provinces. The village selection purposively assured a diversity in: service level of the majority; size of the village or sections included in the study; type of infrastructure, so both self-supply and public infrastructure; water source, so both groundwater resources and surface water in mountainous areas; and in service levels. In all villages, water resources are available, although some sources dry up in the dry winter season (July-September). This means that more distant sources have to be accessed or water use is curtailed. It is noted that all villages have been connected to the electricity grid, except one section, Vrystad, in Phiring.

Table 1 presents the villages, in the order of increasing service levels experienced by the majority of inhabitants. The table includes: total size of the population of the entire village or the sections selected, the sample size and the diversity achieved in water sources, types of infrastructure and whether infrastructure is public or for communal or individual self-supply. The location of the villages is given in Fig. 1.

In each village, the sample of households was randomly selected. A household survey was conducted in 2017 that covered: household composition and livelihood strategies and the related sites of water use. For each site of use, the use(s) and reuse(s) and the various infrastructures with their advantages 
and disadvantages were assessed. An equal or nearly equal proportion of men and women respondents were interviewed. In addition, qualitative interviews with individual irrigators and other resource persons were conducted, and focus group discussions and transect walks held in the course of 2017 and 2018 as part of the ongoing project 'Operationalizing multiple use water services in South Africa'.
Based on the household wellbeing data, households were ranked into relatively poor households (receiving social grants so being categorized as indigent; house with poor materials; often employed as labour; often food insecure; and does not own major livestock such as cattle) and wealthier households (lived in houses with cement, iron and tile roofing materials and multiple rooms; owning cattle - the number of cattle increases their wealth; owning a car and not receiving social grants. The

Table 1. Population size, sample size and diversity of characteristic of the six villages selected

\begin{tabular}{|c|c|c|c|c|c|c|}
\hline \multirow[b]{2}{*}{ Variable } & \multicolumn{6}{|c|}{ Village/district } \\
\hline & $\begin{array}{l}\text { Ga-Moela/ } \\
\text { Sekhukhune }\end{array}$ & $\begin{array}{l}\text { Khalavha/ } \\
\text { Vhembe } \\
\text { (3 of } 5 \text { sections) }\end{array}$ & $\begin{array}{l}\text { Tshakhuma/ } \\
\text { Vhembe } \\
\text { (9 of } 11 \text { sections) }\end{array}$ & $\begin{array}{l}\text { HaGumbu/ } \\
\text { Vhembe }\end{array}$ & $\begin{array}{l}\text { GaMokgotho/ } \\
\text { Sekhukhune }\end{array}$ & $\begin{array}{c}\text { Phiring/ } \\
\text { Sekhukhune }\end{array}$ \\
\hline $\begin{array}{l}\text { Total households } \\
\text { (number) }\end{array}$ & 100 & 600 & 3260 & 342 & 870 & 415 \\
\hline $\begin{array}{l}\text { Sample size (number of } \\
\text { households) }\end{array}$ & 65 & 67 & 250 & 66 & 100 & 97 \\
\hline $\begin{array}{l}\text { Annual precipitation } \\
2015-2016(\mathrm{~mm})\end{array}$ & $513-771$ & $623-1185$ & $604-787$ & $163-325$ & $623-1185$ & $604-787$ \\
\hline Main water resources & $\begin{array}{c}\text { Shallow } \\
\text { groundwater }\end{array}$ & $\begin{array}{l}\text { Mountain spring } \\
\text { and streams }\end{array}$ & $\begin{array}{l}\text { Mountain springs } \\
\text { and streams }\end{array}$ & $\begin{array}{c}\text { Shallow } \\
\text { groundwater }\end{array}$ & $\begin{array}{l}\text { Mountain } \\
\text { springs and } \\
\text { streams }\end{array}$ & $\begin{array}{l}\text { Mountain } \\
\text { streams } \\
\text { and shallow } \\
\text { groundwater }\end{array}$ \\
\hline Main infrastructure & Hand-dug wells & $\begin{array}{l}\text { Gravity piped } \\
\text { system }\end{array}$ & $\begin{array}{l}\text { Gravity piped } \\
\text { system }\end{array}$ & $\begin{array}{l}\text { Mechanized } \\
\text { boreholes }\end{array}$ & $\begin{array}{l}\text { Gravity piped } \\
\text { system }\end{array}$ & $\begin{array}{c}\text { Dam with gravity } \\
\text { irrigation scheme } \\
\text { and borehole }\end{array}$ \\
\hline $\begin{array}{l}\text { Main type: Self-supply } \\
\text { or public; communal or } \\
\text { individual }\end{array}$ & $\begin{array}{l}\text { Self-supply } \\
\text { communal }\end{array}$ & $\begin{array}{l}\text { Self-supply } \\
\text { communal }\end{array}$ & $\begin{array}{l}\text { Self-supply } \\
\text { communal }\end{array}$ & $\begin{array}{l}\text { Self-supply } \\
\text { individual }\end{array}$ & $\begin{array}{l}\text { Public (NGO) } \\
\text { communal }\end{array}$ & Public communal \\
\hline
\end{tabular}

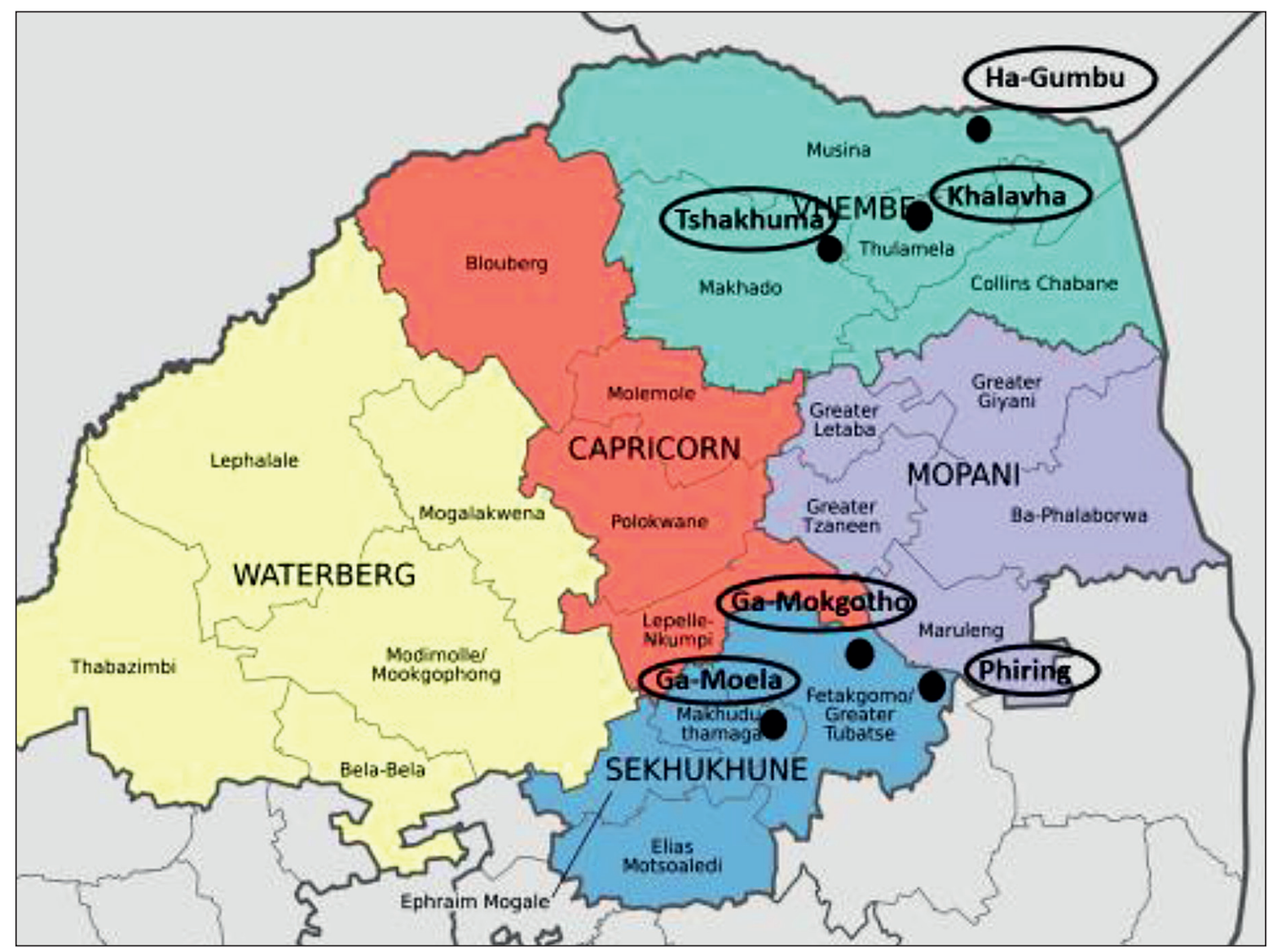

Figure 1. Location of the six demonstration communities in Limpopo Province 
proportion of households that scored as 'poor' varies between $36 \%$ and $60 \%$. See Table A1 (Appendix) for these and other household characteristics.

The results are given according to the site of use: homesteads, distant fields and other sites of use. For each site, findings are presented on the uses and the respective water sources and type of infrastructure for that site of use (public, communal self-supply and individual self-supply), each with perceived advantages and disadvantages. The last two sections summarize the new insights generated and explore policy implications.

\section{RESULTS}

\section{Water use, development and management at homesteads}

\section{Water-dependent livelihoods}

Homesteads are the preferred site for universal water uses of drinking and other domestic uses, which is not further detailed here. In addition, water is used for livestock and cultivation. As shown in Table 2, the proportion of households with livestock (cattle, goats, chicken, and rarely donkeys or pigs) varies considerably, from $18 \%$ in Tshakhuma to $83 \%$ of respondents in Ga-Moela, with ample grazing lands between the scattered houses. Chicken, goats, donkeys and pigs drink at homesteads. Cattle drink both at homesteads and at other sites of use when roaming around or herded in grazing areas (see section 'other sites of use'). In the densely populated setting of Tshakhuma space for livestock is limited.

Table 3 indicates the frequency of homestead cultivation and irrigation. In the rainy summer months, irrigation is supplemental to increase yields by 'keeping the vegetables fresh and healthy' (respondent survey Tshakhuma). Others don't irrigate in the summer and await the rain 'which is already irrigating' (respondent survey Khalavha). Irrigation in the winter enables year-round production.

Half or more of the households that cultivate at homesteads, irrigate, except in Ga-Moela. In the six villages, a variety of produce is grown. Maize and, to a much lesser extent, sorghum are grown as staple crop (and rarely irrigated). Trees, which depend on rainfall and often some irrigation, are mangos, avocados, litchis, papayas, orange, macadamia, or bananas. Vegetables are irrigated and include: mustard, spinach, tomatoes, potatoes, onion, peri-peri, carrots, cabbage, and beetroot. Sugarcane is grown as well. Produce is used for own consumption and surplus, especially irrigated vegetables, is sold. The watering of lawns and flowers appeared important nondomestic uses as well, especially in Phiring and Tshakhuma.

Exploring drivers of homestead irrigation, space seems to be one such driver, both in Tshakhuma and Phiring. Phiring lies on a small strip in-between the foot of the mountain and the irrigation scheme in the valley. The latter already provides for irrigation opportunities as well.

A second driver seems to be water availability in the sense of affordable infrastructure and energy to access available surface or ground water resources. Not surprisingly, therefore, the proportion of households irrigating their homestead, out of all households cultivating their homestead and adjacent land, is lowest in Ga-Moela: just 14\%. Here most people still depend on distant hand-dug wells for any water to their homesteads. In contrast, the proportion of homestead irrigators is highest in Ha-Gumbu (59\% of households). Ha-Gumbu has a low rainfall of less than 325 $\mathrm{mm}$, but ample shallow groundwater resources. Electrification of the village has rendered individual mechanized boreholes more affordable. A total of 96 households of the estimated total of 342 households have installed their own borehole, often with drip irrigation. However, even households without easy access to water can irrigate. In Ha-Gumbu, street taps are not only used for livestock watering but sometimes even for homestead irrigation. Ample water availability in Ga-Mokgotho also enables most households to irrigate trees and vegetables.

The third driver determines the profitability of accessing water: markets. In Ha-Gumbu, irrigated okra, chillies, tomatoes, green pepper, green beans, cabbage and spinach are mostly grown at homesteads. This produce is sold to the City Deep Market of Johannesburg at $600 \mathrm{~km}$ distance. Khalavha sells its avocadoes and vegetables along the main road passing the village. Such market pull is also provided by the local Fresh Market of Tshakhuma, which trades the famous locally grown avocados but also bananas, mangos and vegetables. In all villages, households also sell their surplus homestead produce to traders coming to their houses, to local buyers or at distant markets.

\section{Multiple sources and infrastructure}

Water for the above-mentioned multiple uses comes from multiple sources. In four of the six villages, $71 \%$ to $91 \%$ of the respondents have two or more sources of water to their homesteads, other than rainwater harvesting which is discussed below. In the fifth village, Ga-Moela, this proportion is only $25 \%$, as most people depend on the same type of distant handdug wells. When nearby wells dry out, people have to move to more distant wells. In Phiring, only $38 \%$ of households have at least two sources of water to their homestead. Here, a municipal borehole system provides water for free, every other day to most of the village (except the Vrystad section).

Table 4 presents these sources in further detail. It lists the various types of communal public infrastructure and the communal or individual self-supply infrastructure and indicates the percentage of respondents that see that infrastructure as the

Table 2. Livestock and animal water drinking at homesteads

\begin{tabular}{|c|c|c|c|c|c|c|}
\hline \multirow{2}{*}{ Variable } & \multicolumn{6}{|c|}{ Village/district } \\
\hline & $\begin{array}{c}\text { Ga-Moela/ } \\
\text { Sekhukhune }\end{array}$ & $\begin{array}{l}\text { Khalavha/ } \\
\text { Vhembe }\end{array}$ & $\begin{array}{c}\text { Tshakhuma/ } \\
\text { Vhembe }\end{array}$ & $\begin{array}{c}\text { Ha-Gumbu/ } \\
\text { Vhembe }\end{array}$ & $\begin{array}{l}\text { Ga-Mokgotho/ } \\
\text { Sekhukhune }\end{array}$ & $\begin{array}{c}\text { Phiring/ } \\
\text { Sekhukhune }\end{array}$ \\
\hline Households with livestock (\%) & 83 & 38 & 18 & 56 & 58 & 51 \\
\hline
\end{tabular}

Table 3. Cultivation and irrigation at homesteads

\begin{tabular}{|c|c|c|c|c|c|c|}
\hline \multirow[b]{2}{*}{ Variable } & \multicolumn{6}{|c|}{ Village/district } \\
\hline & $\begin{array}{c}\text { Ga-Moela/ } \\
\text { Sekhukhune }\end{array}$ & $\begin{array}{l}\text { Khalavha/ } \\
\text { Vhembe }\end{array}$ & $\begin{array}{c}\text { Tshakhuma/ } \\
\text { Vhembe }\end{array}$ & $\begin{array}{c}\text { Ha-Gumbu/ } \\
\text { Vhembe }\end{array}$ & $\begin{array}{l}\text { Ga-Mokgotho/ } \\
\text { Sekhukhune }\end{array}$ & $\begin{array}{c}\text { Phiring/ } \\
\text { Sekhukhune }\end{array}$ \\
\hline Households cultivating homesteads (\%) & 73 & 78 & $\sim$ half & 82 & 86 & 24 \\
\hline Households irrigating homesteads (\%) & 14 & 46 & 25 & 59 & most & 24 \\
\hline
\end{tabular}


most important source to their homesteads. Significantly, in four of the six villages more than half of the respondents find the self-supply infrastructure the most important source for their homesteads. Only in Ga-Mokgotho and Phiring do people rely on the public scheme.

People's perceptions of the advantages and disadvantages of the various types of infrastructure are given in Table 4 and nonfunctional schemes are discussed next.

\section{Public schemes}

In all villages, except Ga-Mokgotho, municipalities have constructed public schemes for basic domestic needs. They also operate these schemes through employed and paid (or incidentally voluntary) pump operators. Municipalities are also responsible for managing and repairing breakdowns. Water is provided for free, as part of the Free Basic Water regulation of $6000 \mathrm{~kL}$ per household per month. No village does any metering or is billed for the higher volumes used. In Ga-Mokgotho, an NGO installed a public gravity system with some 100 street taps. This was handed over to the community, which now operates the system on its own.

Respondents who received water from municipal schemes welcomed the public provision of quite clean water for free. However, the quantities are often low because the design was only for basic domestic needs. Street taps curtail water use. Even with household connections, as in Tshakhuma and Phiring, respondents complained about rotation schedules, or, more often, irregularity and unpredictability. Reportedly, Tshakhuma's system only delivers water once a week to respective sites. Municipalities may also fail to bring diesel in time, so communities organize themselves to buy diesel, as found in Ga-Moela. For the mechanized boreholes, it takes very long before municipalities address even small breakdowns (Ga-Moela, Phiring). In addition to disruptions because of electricity outages, the municipality may fail to pay their municipal electricity bill so the pump is closed, as reported in Phiring. In $\mathrm{Ha}-\mathrm{Gumbu}$, the rehabilitation from a diesel engine to an electric engine takes months. Schemes further dilapidate because there is hardly any preventive maintenance and protection of infrastructure from playing children, cars or vandalism. During all those periods of disruptions, people need back-ups, typically in the form of temporary and permanent self-supply. In Phiring, the public irrigation pipe provides such back-up water but the dam is dry in the dry season.

Other respondents don't receive water from the municipal scheme at all. Reticulation is missing and street taps are too far from existing sections (as for most of Ga-Moela or the Vrystad section in Phiring). New sections to accommodate rapid population influx and expansion are not reached either (as in Ga-Mokgotho and Ha-Gumbu). For them, self-supply is the only option.

In four of the six villages one or more municipal investments in mechanized boreholes either failed completely or the newly constructed boreholes with or without reticulation schemes remain unused: Ga-Moela (three failed borehole systems), Khalavha (one failed borehole), Tshakhuma Maswie section (one borehole unused and without reticulation), and Vrystad Phiring (four failed borehole investments, while one electric borehole with reticulation still awaits electrification). The materials used have either been stored, or taken away to use elsewhere, or have disappeared.

\section{Self-supply}

\section{Communal self-supply}

Self-supply has existed since time immemorial. The most elementary form is accessing shared open water bodies. In Ga-Moela, streams and wetlands are still the most important source for $15 \%$ of the people. In Khalavha and Phiring, this is only the case for very few respondents. For others, this is still a back-up source in case of droughts or the failure of other sources.

In all other cases, there is some development and management of communal self-supply. In Ga-Moela, $57 \%$ of the respondents access over 20 traditional hand-dug wells. These are seen as communal property and used and managed by groups of nearby homesteads. Traditionally, some wells were reserved for human consumption, preventing animals from drinking. Also, till today, some hand-dug wells are constructed in such manner that the

Table 4. Percentage of households by type of infrastructure that is seen as the most important source of water at homesteads

\begin{tabular}{|c|c|c|c|c|c|c|c|}
\hline \multirow{2}{*}{$\begin{array}{l}\text { Village } \\
\text { (in order of } \\
\text { service level) }\end{array}$} & \multicolumn{2}{|c|}{ Public communal/municipal } & \multicolumn{2}{|c|}{ Communal self-supply } & \multicolumn{2}{|c|}{ Individual self-supply } & \multirow{2}{*}{$\begin{array}{c}\text { Total } \\
\%\end{array}$} \\
\hline & Type & $\begin{array}{c}\% \text { most } \\
\text { important }\end{array}$ & Type & $\begin{array}{c}\% \text { most } \\
\text { important }\end{array}$ & Type & $\begin{array}{c}\% \text { most } \\
\text { important }\end{array}$ & \\
\hline \multirow[t]{2}{*}{ Ga-Moela } & \multirow{2}{*}{$\begin{array}{l}2 \text { boreholes with few } \\
\text { street taps }\end{array}$} & \multirow[t]{2}{*}{15} & Shallow wells & 57 & \multirow{2}{*}{$\begin{array}{l}\text { Gravity pipes } \\
\text { from streams }\end{array}$} & \multirow[t]{2}{*}{12} & \multirow[t]{2}{*}{99} \\
\hline & & & River or spring & 15 & & & \\
\hline \multirow[t]{2}{*}{ Khalavha } & \multirow{2}{*}{$\begin{array}{l}1 \text { borehole scheme } \\
\text { with both street } \\
\text { taps and household } \\
\text { connection }\end{array}$} & \multirow[t]{2}{*}{45} & $\begin{array}{l}2 \text { gravity schemes } \\
\text { serving } 97 \\
\text { households }\end{array}$ & 46 & Borehole & 4 & \multirow[t]{2}{*}{99} \\
\hline & & & River & 3 & Purchase & 1 & \\
\hline Tshakhuma & $\begin{array}{l}1 \text { gravity scheme } \\
\text { with household } \\
\text { connections }\end{array}$ & 28 & $\begin{array}{l}11 \text { gravity schemes } \\
\text { serving } 2360 \\
\text { households }\end{array}$ & 72 & - & 0 & 100 \\
\hline \multirow[t]{2}{*}{ Ha-Gumbu } & $\begin{array}{l}1 \text { borehole scheme } \\
\text { with street taps }\end{array}$ & 26 & \multirow[t]{2}{*}{-} & \multirow[t]{2}{*}{-} & Own borehole & 32 & \multirow[t]{2}{*}{99} \\
\hline & 1 hand pump & 23 & & & Purchase & 18 & \\
\hline Ga-Mokgotho & $\begin{array}{l}1 \text { gravity scheme (by } \\
\text { NGO) with street taps }\end{array}$ & 89 & & - & $\begin{array}{l}\text { Gravity pipe } \\
\text { from neighbours }\end{array}$ & 11 & 100 \\
\hline \multirow[t]{2}{*}{ Phiring } & $\begin{array}{l}1 \text { borehole scheme } \\
\text { with household } \\
\text { connections }\end{array}$ & 94 & \multirow[t]{2}{*}{$\begin{array}{l}\text { Small gravity } \\
\text { scheme }\end{array}$} & \multirow[t]{2}{*}{4} & \multirow[t]{2}{*}{ Borehole } & \multirow[t]{2}{*}{1} & \multirow[t]{2}{*}{100} \\
\hline & 1 irrigation scheme & 1 & & & & & \\
\hline
\end{tabular}


upper part is used for human consumption, and a separated lower part is open for animals. But in all other cases, these arrangements have been eroded - animals drink as well, and soils, dung and other dirt flows into the wells, especially when it rains.

Elsewhere, investments in communal self-supply are more recent. In Tshakhuma and Khalavha groups of villagers organized in the past decade to contribute money to install new piped gravity systems to considerably improve their access to water for multiple uses. The systems take water from mountain springs and streams. Polyethylene pipes (or polypipes) lead water to reservoirs before reticulation to all contributing households. The reservoirs are sometimes chlorinated. Or there are no reservoirs, as in one system in Tshakhuma and two systems in Khalavha. Gravity-driven energy, technical skills learnt elsewhere and further developed-by-doing and mutual exchange, and the ready availability of polypipes and plastic tanks ('jojo tanks') enabled these gravity systems. In Ga-Mokgotho and Vrystad, Piring, similar initiatives have been taken by much smaller groups.

Whereas these schemes are a tangible improvement compared to the earlier situation, the aspired 24/7 services are exceptional. Respondents mentioned similar complaints as for municipal systems with regard to the reliability and predictability of rotations, especially in larger schemes. Also, operation and maintenance are intensive. The low-quality pipes and joints may disconnect, requiring long walks up to the source to reconnect. Yet operation and maintenance mainly rely on voluntary or ad hoc contributions, which may jeopardize sustainability in the long run.

\section{Individual self-supply}

In all villages, one or a few wealthier respondents and others invested in their own homestead boreholes. Moreover, in Ga-Mokgotho, households (outside the sample) installed individual polypipes from mountain streams to their homesteads, adding to the water provided by the street taps. As mentioned, individual self-supply is most pronounced in $\mathrm{Ha}-\mathrm{Gumbu}$, where individual electric boreholes are the most important source of water at homesteads for $32 \%$ of the respondents. The generation of a net revenue from productive water uses at their yards was the main driver; the availability of the much smaller volumes of water required for domestic uses was an additional advantage.

A form of self-supply grafted on public schemes are household connections from a common main line of a public scheme. In Phiring's borehole scheme, all households agreed to make such connections at their own costs. In Ga-Moela, one household negotiated such connection to the public borehole scheme. Household connections often happen without common agreement. In particular, in Ga-Mokgotho many individuals changed the street taps into household connections, either by temporarily connecting a polypipe to the more elevated tap so that water flows in turns to homesteads, or by a new reticulation shared by some neighbours, or by an entirely new connection. This was not regulated and became the private income source for the non-paid operator.

\section{Sharing of water}

An important form of self-supply is the sharing of water, whether obtained from public schemes or from self-supply infrastructure. When people receive water for free, sharing of water with neighbours is a free service as well, as found for example in Ga-Mokgotho to be the most important source of water for $11 \%$ of the respondents. However, water needs to be bought when the seller incurs significant costs as well. Water markets emerge in which borehole owners not only use water at their own homesteads but also sell water on a regular basis to neighbours. For example, in Ha-Gumbu, $18 \%$ depend on a neighbour's private borehole as their main source for domestic uses. The costs vary between R1 and R5 per container. Or a monthly amount of R100 or R150 is paid as contribution to the pumping costs. These costs are an obvious disadvantage. Also, a respondent noted: 'Sometimes the man in the house talks in a bad manner'. Another respondent remarked: 'One gets tired of always asking for water'.

Last but not least, in all villages there are water vendors, who meet water needs during exceptionally big ceremonies or other large events, or during droughts or other periods of scarcity, or permanently if there is no other option.

\section{Self-supply storage, rainwater harvesting and reuse}

Within homesteads, there are other forms of self-supply as well: storage, rainwater harvesting and reuse. Table 5 presents the findings.

Homestead storage enables, among others, buffering against natural water resource variability and irregular supplies, breakdowns or other interruptions. Storage (at any point between the intake and the homestead) also regulates pressure. Allegedly, the filling of elevated homestead storage by boreholes limits the costs of repeatedly switching on a pump. Homestead storage also allows for catching roof-harvested rainwater.

Virtually all responding households invest in storage. They do this in containers of about $20 \mathrm{~L}$, or drums of $200 \mathrm{~L}$ or more, or jojo tanks of 2500,5000 , or $10000 \mathrm{~L}$. The proportion of households with jojo tanks is highest in Khalavha, at $17 \%$. Households tend to continuously fill storage; it is very rare for households to use up all water stored before it is completely filled again.

The average total volume of all homestead storage equipment together is given in Table 5, and is around $1000 \mathrm{~L}$ per household. This is also related to the wealth status. The average storage volume of households scored as relatively poorer is consistently lower than that of relatively wealthier households. Ha-Gumbu is the exception: it both has a somewhat lower average of $829 \mathrm{~L}$ and

Table 5. Self-supply within homesteads

\begin{tabular}{|c|c|c|c|c|c|c|}
\hline \multirow[b]{2}{*}{ Variable } & \multicolumn{6}{|c|}{ Village/district } \\
\hline & $\begin{array}{l}\text { Ga-Moela/ } \\
\text { Sekhukhune }\end{array}$ & $\begin{array}{l}\text { Khalavha/ } \\
\text { Vhembe }\end{array}$ & $\begin{array}{l}\text { Tshakhuma/ } \\
\text { Vhembe }\end{array}$ & $\begin{array}{l}\text { Ha-Gumbu/ } \\
\text { Vhembe }\end{array}$ & $\begin{array}{l}\text { Ga-Mokgotho/ } \\
\text { Sekhukhune }\end{array}$ & $\begin{array}{l}\text { Phiring/ } \\
\text { Sekhukhune }\end{array}$ \\
\hline Average volume of homestead storage (L) & 1046 & 1257 & 951 & 829 & 1138 & 1191 \\
\hline $\begin{array}{l}\text { Average volume of homestead storage, } \\
\text { poorer-wealthier households (L) }\end{array}$ & $721-1438$ & $830-1512$ & $833-1094$ & $908-782$ & $1131-1148$ & $965-1349$ \\
\hline Households with jojo tanks (\%) & 6 & 17 & 13 & 10 & 15 & 16 \\
\hline $\begin{array}{l}\text { Households harvesting rainwater at } \\
\text { homesteads (\%) }\end{array}$ & 90 & 85 & 86 & 100 & 79 & 71 \\
\hline Households reusing water at homesteads (\%) & 80 & 57 & 66 & 57 & 58 & 58 \\
\hline
\end{tabular}


an inverse relation between wealth and water storage volume. An explanation can be that those who have their own boreholes see the aquifer as reliable year-round storage.

Table 5 also shows that rainwater harvesting is very common. Practices range from well-designed roofs with gutters and storage to capture water to just putting buckets outside. The minority who do not harvest rainwater lack the proper corrugated iron or tiled roofs, gutters and/or storage, or have sufficient water for current needs. There is some interest in taking up or expanding rainwater harvesting, which would require the appropriate infrastructure.

Well over half of the households reuse water at homesteads, with the highest proportion of $80 \%$ in water-scarce Ga-Moela, as indicated in Table 5. The pattern is quite similar across the six villages. Households reuse water that was used for washing, bathing or laundry. This is used to irrigate trees, flowers, lawns, and sometimes vegetables; or for cleaning floors or washing cars. To a lesser extent, water is mixed with cow dung for repair and plastering of walls and floors and building purposes. Those who do not reuse any water stated that they have enough water, and that used water is dirty. Soap, in particular, would harm the plants. Others explained that they lack the trees or crops to water, or the skills to reuse water.

\section{Water quality and sanitation}

With regard to health and hygiene, a majority perceives the quality of water used for drinking and cooking as sufficient or good in five villages (see Table 6). However, this percentage is only 28 in Ga-Moela, because of their dependence on open springs, rivers and hand-dug wells, where they share water with the animals that $82 \%$ of households own, as mentioned in Table 2 .

Complaints about the water quality are found in the communal gravity systems for self-supply. Debris enters the polypipes at the intake, especially when it rains. Also, water gets filthy when several parts of the pipes disconnect, for example, because of excessive pressure and low-quality fittings and clamps. Those who access open surface bodies, as in the section Vrystad of Phiring, also complain about the water quality.

There are less complaints about the water quality of public systems. But when the engine breaks down or similar, water can become dirty (Ha-Gumbu). Further, schoolboys or cars and construction works may damage pipes, which also leads to pollution (Phiring, Tshakhuma, Ga-Mokgotho).
Some respondents in Ha-Gumbu complained about salinity, bad smell, or bad colour of pumped (and often stored) groundwater.

In spite of these concerns, the percentage of respondents that say they treat water is low, except in Ga-Moela and Khalavha. Moreover, such treatment often occurs incidentally, at best. Common treatments are boiling water, letting water stand to settle, or adding bleach. The Department of Water and Sanitation (DWS), as 'the eye' of government, used to distribute bleach. However, in Tshakhuma, it was noticed how this bleach is used for the laundry instead.

Household pit latrines are common. In-house flush toilets are rare. With the exception of Ga-Moela, open defaecation is virtually absent.

Lastly, another water-borne health problem is malaria. This was articulated most in Phiring, even though Phiring has not been considered to be malaria-prone in the past. Yet, several fatal cases of malaria had occurred, which were ascribed to open water sources. The irrigation scheme may contribute to malaria as well.

\section{Water use, development and management at distant fields}

\section{Water-dependent livelihoods}

In this study's conceptual approach, the second site of water use is the distant field that is irrigated, either in a public scheme or through self-supply. As identified in the sample (Table 7) and also through separate interviews, irrigation of distant fields is rare compared to irrigation at homesteads.

\section{Public infrastructure}

Irrigation is most frequent in Phiring, the only village among the six with a public irrigation scheme, constructed by Government. An upstream dam provides water to a central main pipe with reticulation to each field within the 380 -ha scheme. However, every winter since 2016 the dam has dried up, but there is still soil moisture and groundwater in this valley. Water is provided without charge. Operation and maintenance are in the hands of the farmers. In the rainy season, maize and vegetables are grown; irrigation is supplemental, or cultivation is entirely rainfed. In the dry winters, vegetables are grown and sold to traders who come to the scheme or at local and distant markets. Prices are low and inputs are expensive. A number of fields are not cultivated at all.

Table 6. Households' perceptions of water quality and treatment

\begin{tabular}{|c|c|c|c|c|c|c|}
\hline \multirow[b]{2}{*}{ Variable } & \multicolumn{6}{|c|}{ Village/district } \\
\hline & $\begin{array}{c}\text { GaMoela/ } \\
\text { Sekhukhune }\end{array}$ & $\begin{array}{l}\text { Khalavha/ } \\
\text { Vhembe }\end{array}$ & $\begin{array}{l}\text { Tshakhuma/ } \\
\text { Vhembe }\end{array}$ & $\begin{array}{l}\text { HaGumbu/ } \\
\text { Vhembe }\end{array}$ & $\begin{array}{l}\text { GaMokgotho/ } \\
\text { Sekhukhune }\end{array}$ & $\begin{array}{l}\text { Phiring/ } \\
\text { Sekhukhune }\end{array}$ \\
\hline $\begin{array}{l}\text { Households satisfied about the quality of } \\
\text { water for drinking and cooking (\%) }\end{array}$ & 28 & 60 & 78 & 67 & 83 & $\sim 90$ \\
\hline Households sometimes treating water (\%) & 30 & 28 & 3 & 10 & 9 & 9 \\
\hline Households with flush toilet (\%) & 1 & 12 & 5 & 3 & 0 & 2 \\
\hline Households without any toilet (\%) & 25 & 1 & 0.2 & 0 & 0 & 8 \\
\hline
\end{tabular}

Table 7. Households cultivating and irrigating distant fields

\begin{tabular}{|c|c|c|c|c|c|c|}
\hline \multirow[b]{2}{*}{ Variable } & \multicolumn{6}{|c|}{ Village/district } \\
\hline & $\begin{array}{l}\text { Ga-Moela/ } \\
\text { Sekhukhune }\end{array}$ & $\begin{array}{l}\text { Khalavha/ } \\
\text { Vhembe }\end{array}$ & $\begin{array}{l}\text { Tshakhuma/ } \\
\text { Vhembe }\end{array}$ & $\begin{array}{l}\text { Ha-Gumbu/ } \\
\text { Vhembe }\end{array}$ & $\begin{array}{l}\text { Ga-Mokgotho/ } \\
\text { Sekhukhune }\end{array}$ & $\begin{array}{l}\text { Phiring/ } \\
\text { Sekhukhune }\end{array}$ \\
\hline Households cultivating distant field (\%) & 48 & 29 & Few & 23 & Few & Many \\
\hline $\begin{array}{l}\text { Households winter irrigation distant } \\
\text { field (\%) }\end{array}$ & 5 & 5 & 1 & 5 & Very few & $\begin{array}{l}\text { A significant } \\
\text { proportion }\end{array}$ \\
\hline
\end{tabular}


A dip tank is connected to the pipe as well. The irrigation pipe is also used daily by households from Vrystad and by two downstream villages for their basic domestic needs. Further, many households use the irrigation pipes to provide water for domestic uses, even including drinking water, to fill the gap between rotations and in case of disruptions in water provision from the borehole. So this irrigation scheme is, de facto, a multiple-use system.

\section{Individual self-supply and sharing}

Individual self-supply to distant fields was found to be single use. In Ga-Moela, a few people channel water from streams through pipes to their fields for vegetable cultivation. A small fertile valley near Ga-Mokgotho is irrigated by various farmers, each with individual long gravity pipes taking water from elevated mountain streams. An orchard in the midst of the residential area is irrigated in this way as well. In Ha-Gumbu, some smallholders have installed boreholes at their fields. However, even for such distant fields, there are exceptions: one household installed a borehole at the homestead for homestead uses, and, through a long polypipe, the borehole irrigates a distant field as well.

In Phiring, one irrigator addressed the drying up of the dam in the dry winter season by installing a borehole at his field to pump the shallow groundwater. Others purchased a motor pump to lift water out of the adjacent river. Some share their pumps with others for some compensation. All these individual technologies for self-supply are single-use, being only for irrigation. However, these are the few cases in which a distant field is irrigated by more than one source. No examples were found of communal self-supply initiatives to provide water to distant fields.

\section{Water use, development and management at other sites of water use}

In addition to homesteads and distant fields as two sites of water use, the third category refers to all 'other sites of water use' for people and their livestock. These sites include the surroundings of distant wells, excavated ponds, dams, weirs, and naturally available open surface water bodies. Table 8 lists the survey findings on the livelihoods that depend on the various other sites of use.

Cattle watering can take place in hand-dug wells (as in Ga-Moela and Tshakhuma) or communal reservoirs for self-supply in designated grazing areas, as in Phiring. Cattle and wildlife also drink from springs and streams, including the Limpopo River near Ha-Gumbu. This river was also the only place found to be used for fisheries.

Other common water uses in streams are bathing and laundry, or even washing utensils and taking water for drinking, wherever and whenever water supplies to homesteads fail. Car-washing or other enterprises also use water resources available at such sites However, crocodiles are reported to seriously threaten people and animals.

\section{DISCUSSION AND CONCLUSION}

A closer look at how poor rural people develop and manage water at community level may be a daunting analysis of 'spaghettis' of multiple locally specific water sources, many locally feasible or desired needs, and many types of multiple-use or singleuse infrastructure financed by the public sector or users or a combination thereof. However, three patterns stand out.

\section{Self-supply is there to stay}

First, findings confirm the importance of the global debates: selfsupply is there to stay, both for domestic and productive uses. Self-supply comes in various forms: communal and individual; and as standalones and grafted on public infrastructure. Reliance on self-supply can imply very low service levels, as in Ga-Moela. However, in the five other villages, self-supply enables people to improve their access to water faster than Government on its own does. This is likely to continue in the near future. Selfsupply is enabled by accessible water resources (gravity flows and shallow groundwater); the availability of affordable water infrastructure with low gravity or electricity costs; local technical knowledge; market incentives; and the remarkable abilities in some communities to organize for collective action. Such faster improvement in access to water contributes to faster realization of greater wellbeing of expanding populations, in line with constitutional rights and policy aspirations. However, selfsupply requires investments that the poorest cannot afford. This may widen social and gender gaps both within and between communities. Yet, the poorest may still benefit from trickle-down effects of water sharing, faster than Government can provide.

\section{Alternative sources as buffer}

Second, this community-scale analysis highlights combinations of multiple sources, in particular the existence of two or more sources to homesteads (and homestead-based storage) and sources at distant fields and elsewhere. These are vital 'fall-back' options in case of failing public infrastructure or during the dry season, dry spells or other extreme events. Alternatives limit communities' dependency on public infrastructure. This may contribute to passiveness when public infrastructure fails or is vandalized, and to further reliance on alternatives when tariffs are introduced in public schemes.

\section{Multiple-use infrastructure is normal; single-use is the exception}

A third pattern in community-scale analysis of any infrastructure is that infrastructure is normally multiple use; single-use is the exception. Infrastructure that provides water to homesteads is typically multiple use for most households. The homestead is a micro-cosmos of integrated management of water from multiple sources, for multiple uses, with storage development, rainwater harvesting and water reuse. Supplemental or year-round irrigation is the most frequent productive use. As in $\mathrm{Ha}-\mathrm{Gumbu}$, profitable irrigation opportunities trigger investments in multiple-use self-supply that enables domestic uses as well. Importantly, homestead-based production is accessible to everyone, including those without land and who are less mobile. This overcomes the irrigation sector's limited attention to equity issues and ignoring of the landless. Instead, it aligns with the WASH sector's focus on everybody's homesteads as the most equal opportunity for productive water uses possible.

Table 8. Households (percentage) using water at other sites (with purpose)

\begin{tabular}{|c|c|c|c|c|c|c|}
\hline \multirow{2}{*}{ Variable } & \multicolumn{6}{|c|}{ Village/district } \\
\hline & $\begin{array}{c}\text { GaMoela/ } \\
\text { Sekhukhune }\end{array}$ & $\begin{array}{l}\text { Khalavha/ } \\
\text { Vhembe }\end{array}$ & $\begin{array}{l}\text { Tshakhuma/ } \\
\text { Vhembe }\end{array}$ & $\begin{array}{l}\text { HaGumbu/ } \\
\text { Vhembe }\end{array}$ & $\begin{array}{l}\text { GaMokgotho/ } \\
\text { Sekhukhune }\end{array}$ & $\begin{array}{l}\text { Phiring/ } \\
\text { Sekhukhune }\end{array}$ \\
\hline $\begin{array}{l}\text { Households accessing other } \\
\text { sites of use and purpose (\%) }\end{array}$ & $\begin{array}{c}27 \text { (cattle) } \\
20 \text { (laundry) }\end{array}$ & $\begin{array}{l}19 \text { (cattle, laundry, } \\
\text { bathing) }\end{array}$ & $\begin{array}{l}\text { Few (car-washing, } \\
\text { laundry, cattle) }\end{array}$ & 20 (cattle) & Few (cattle) & 32 (cattle) \\
\hline
\end{tabular}


Water infrastructure to distant fields is also multiple use in the case of the conventional irrigation scheme, as in Phiring. However, close-by point sources and individual self-supply infrastructure to distant fields is the exceptional single use. Other sites are also used for multiple purposes, as back-up domestic uses that require larger quantities of water and for livestock and enterprises. Single-use infrastructure such as livestock dams are the exception.

Obviously, this finding that multiple-use infrastructure is normal, and single-use an exception, in six low-income villages cannot be generalized. More empirical research is needed. However, this pattern may be a more holistic and realistic conceptual starting point than the conventional assumptions, either in the WASH sector (water infrastructure near or at homesteads is only used for domestic purposes) or in the irrigation sector (irrigation schemes are single use and any individual self-supply is single use, even if installed at or near homesteads), while both overlook other sites of use.

These three key findings inform the following policy recommendations.

\section{Policy recommendations}

\section{Harnessing the cost effectiveness and water efficiency of multiple-use infrastructure}

Multiple-use infrastructure is cost-effective and water-efficient and operationalizes South Africa's goals to 'climb the water ladder' in water provision to everybody's homesteads. Livestock watering and productive uses and reuses may well have a higher priority than luxury domestic uses. Hence, de-facto multiple uses of public 'domestic' or 'irrigation' schemes could be encouraged wherever water resources and discharges allow. However, those who use more water should contribute more to the infrastructure costs.

\section{Leveraging communities' investments in self-supply and co-management}

Instead of ignoring communities' investments in water infrastructure or even declaring these illegal, these investments can be leveraged as welcome contributions to filling the financing gap of water infrastructure development and to the realization of constitutional rights and inclusive growth. States keep the important responsibility to ensure that those still left behind are also reached and inequalities are narrowed.

Individual or communal self-supply can be supported by strengthening supply chains of affordable technologies, training in engineering skills among women and men, and exchange between villages. In many cases, co-management in publicpublic partnerships can be formalized through service level agreements. For example, public agencies can take care of bulk supplies, such as communal boreholes, whereas communities take charge of the reticulation. Users can pay for connections between main pipes and households. Fuel purchase or small repairs can also be left to communities so that Government can focus on swift implementation of bigger repairs. Government's electrification or, in the future, solar or other renewable energy sources indirectly supports affordable pumping.

The expertise of the irrigation sector to enhance crop productivity and develop markets should assist everybody who wants to cultivate their homesteads as the most equitable productive water use.

The health and hygiene expertise of the WASH sector is relevant for any water source used for drinking. In high-income settings, there is a new interest in separating supplies for water of drinking water quality from supplies for other uses, but costs of separate supplies are often prohibitive. In under-served low- and middleincome areas, this costly long-term solution can be avoided by concentrating efforts on treating only the 3-5 L per capita per day needed for drinking and cooking, for example through point-of-use treatment, wherever spring water and mountain streams or groundwater are unsafe for drinking. Sources can also be protected against pollution by animals or debris flowing into intakes and wells. Even though service levels for 'domestic uses' are 25 if not $50 \mathrm{~L}$ per capita per day, it would be a waste of resources to pursue drinking water quality for other water uses, such as bathing or cleaning floors.

\section{Enabling community-driven water services}

Last but not least, a community-scale analysis along the lines presented here can serve as the diagnostic starting point of holistic participatory planning, design and implementation. In each specific locality, such participatory approaches would take entire communities as entry point and respect their ideas and priorities for incremental improvements. This would sustainably realize the above-mentioned advantages. Since time immemorial, community-scale livelihood strategies, socioeconomic and political relations, institutions, rules and culture, including their inequalities and social safety nets, have shaped water needs and opportunities, infrastructure (co-)ownership, operation and maintenance, and negotiated claims to all water resources. Community-driven water services for multiple uses tap into this ability to manage complexity more effectively than specialist support agencies that focus on a single water use or single infrastructure.

\section{ACKNOWLEDGEMENTS}

The research findings presented in this paper are part of the project 'Operationalizing community-driven multiple-use water services in South Africa'. This project is supported by the African Water Facility of the African Development Bank, and managed by the Water Research Commission, South Africa, as recipient. Implementers are the International Water Management Institute and Tsogang Water and Sanitation. The author gratefully acknowledges the Facility's financial and substantive support. We thank Kenny Pasha, Tjalling 't Hart and Emma Mukwevho for their assistance during this study. The views are those of the authors, who also take responsibility for any remaining inaccuracies or mistakes.

\section{REFERENCES}

ADAMS W, WATSON E and MUTISO S (1997) Water, rules and gender: Water rights in an indigenous irrigation system, Marakwet, Kenya. Dev. Change 28 707-730. https://doi.org/10.1111/1467-7660.00061

BALZER T (2019) National Water \& Sanitation Master Plan. Valuing water dignifying sanitation. Powerpoint presentation at World Water Day. Leaving no-one behind: Water for All, 22 March 2019. Department of Water and Sanitation, Pretoria.

BUTTERWORTH J, SUTTON S and MEKONTA L (2013) Self-supply as a complementary water services delivery model in Ethiopia. Water Altern. 6 (3) 405-423.

COUSINS T, SMITS S and CHAUKE T (2007) Access to water and poor peoples' livelihoods: the case of Ward 16 of Bushbuckridge Local Municipality. Bushbuckridge: AWARD, IRC and Challenge Program on Water and Food. URL:https://www.musgroup.net/sites/ default/files/7e5f6830c0d892e33bf21696b1b5f32f.pdf (Accessed 15 July 2019)

DWAF (Department of Water Affairs and Forestry, South Africa) (2003) Strategic Framework for Water Services. Department of Water Affairs and Forestry, Pretoria.

DWA (Department of Water Affairs, South Africa) (2013) National Water Resource Strategy. June 2013 Second Edition. Department of Water Affairs, Pretoria.

DWS (Department of Water and Sanitation, South Africa) (2018) Draft 
Norms and Standards for Domestic Water Supply and Sanitation. Department of Water and Sanitation, Pretoria.

GIORDANO M, DE FRAITURE C, WEIGHT E and VAN DER BLIEK J (eds) (2012) Water for wealth and food security: supporting farmer-driven investments in agricultural water management. Synthesis report of the AgWater Solutions Project. International Water Management Institute (IWMI), Colombo. 48 pp. https://doi. org/10.5337/2012.207

MORIARTY P, BUTTERWORTH J and VAN KOPPEN B (eds) (2004) Beyond Domestic. Case Studies on Poverty and Productive Uses of Water at the Household Level. IRC Technical Papers Series 41. IRC Water and Sanitation, Delft.

NAIDOO N, CHIDLEY C, MAIN G and VRDOLJAKM (2009) Productive useofdomesticpipedwaterforsustaininglivelihoodsinpoorhouseholds. WRC Report No. TT 412/09. Water Research Commission, Pretoria. OSTROM E (1992) Crafting Institutions for Self-Governing Irrigation Systems. ICS Press, Institute for Contemporary Studies, San Francisco.

RAMUGONDO RR, DIKGWAHTLHE SB, LEKALAKALA RG and SAMBO DC (2013) Identification of small-scale water infrastructure in Nebo Plateau, South Africa. Output 5.3. Internal draft. Challenge Program Water and Food and Agricultural Research Council, Pretoria.

PEREZ DE MENDIGUREN CASTRESANA JC (2004) Productive uses of water at the household level: evidence from Bushbuckridge, South Africa. In: Moriarty P, Butterworth J and Van Koppen B (eds). 2004. Beyond Domestic. Case Studies on Poverty and Productive Uses of Water at the Household Level. IRC Technical Papers Series 41. IRC Water and Sanitation, Delft.

RENWICK M, JOSHI D, HUANG M, KONG S, PETROVA S, BENNETT G, BINGHAM R, FONSECA C, MORIARTY P, SMITS S, BUTTERWORTH J, BOELEE E and JAYASINGHE G (2007) Multiple Use Water Services for the Poor: Assessing the State of Knowledge. Winrock International, Arlington, VA.

SADC/DANIDA REGIONAL WATER SECTOR PROGRAMME (2009) Guidelines for local-level integrated water resource management.
Based on experiences from integrated water resource management demonstration projects in Malawi, Mozambique, Namibia, Swaziland, and Zambia. Synthesized by Barbara van Koppen, Ole Houmoller and Tanja Kruger. Southern African Development Community/Danish International Development Agency and the International Water Management Institute, Pretoria.

SHAH T (2009) Taming the Anarchy: Groundwater Governance in South Asia. RFF Press, Washington DC. https://doi. org/10.4324/9781936331598

SUTTON S, BUTTERWORTH J and MEKONTA L (2012) A hidden resource: Household-led rural water supply in Ethiopia. IRC International Water and Sanitation Centre, The Hague. URL: https:// www.ircwash.org/sites/default/files/a_hidden_resource_web_ version_aug_2013.pdf (Accessed 15 July 2019).

VAN KOPPEN B, SMITS S, RUMBAITIS DEL RÍO C and THOMAS J (2014). Scaling Multiple Use Water Services: Accountability in Public Water Sector Performance for Health and Wealth. Practical Action Publishing UK, Rugby, Warwickshire. https://doi. org/10.3362/9781780448299

VAN KOPPEN B, NHAMO L, CAI X, GABRIEL MJ, SEKGALA M, SHIKWAMBANA S, TSHIKOLOMO K, NEVHUTANDA S, MATLALA B, and MANYAMA D (2017) Smallholder irrigation schemes in the Limpopo Province, South Africa. IWMI Working Paper 174. International Water Management Institute (IWMI), Colombo. https://doi.org/10.5337/2017.206

WORLD BANK (2018) Innovation, entrepreneurship, positive change. Join the farmer-led irrigation revolution. Feature story 5 September 2018. URL: https://www.worldbank.org/en/news/ feature/2018/09/05/innovation-entrepreneurship-positive-changejoin-the-farmer-led-irrigation-revolution (Accessed 15 July 2019).

WOODHOUSE P, VELDWISCH GJ, VENOT JP, BROCKINGTON D, KOMAKECH H and MANJICHI Â (2016) African farmerled irrigation development: re-framing agricultural policy and investment? J. Peasant Stud. 44 (1) 213-233. https://doi.org/10.1080/ 03066150.2016.1219719 
APPENDIX

Table A1. Characteristics of sampled households (percentage)

\begin{tabular}{|c|c|c|c|c|c|c|}
\hline \multirow[b]{2}{*}{ Variable } & \multicolumn{6}{|c|}{ Village/district } \\
\hline & $\begin{array}{l}\text { Ga-Moela/ } \\
\text { Sekhukhune }\end{array}$ & $\begin{array}{l}\text { Khalavha/ } \\
\text { Vhembe }\end{array}$ & $\begin{array}{l}\text { Tshakhuma/ } \\
\text { Vhembe }\end{array}$ & $\begin{array}{l}\text { HaGumbu/ } \\
\text { Vhembe }\end{array}$ & $\begin{array}{l}\text { GaMokgotho/ } \\
\text { Sekhukhune }\end{array}$ & $\begin{array}{l}\text { Phiring/ } \\
\text { Sekhukhune }\end{array}$ \\
\hline Total households (number) & 100 & 600 & 3260 & 342 & 870 & 415 \\
\hline Average family size (persons) & 6.5 & 5.5 & 6 & 5.4 & 6.2 & 5.2 \\
\hline Female-headed households (\%) & 67 & 42 & 44 & 44 & 41 & 46 \\
\hline Household heads without schooling (\%) & 45 & 9 & 12 & 20 & 17 & 27 \\
\hline $\begin{array}{l}\text { Household heads with secondary or } \\
\text { tertiary education (\%) }\end{array}$ & 34 & 66 & 59 & 54 & 60 & 53 \\
\hline Households with a migrant (\%) & 48 & 61 & 30 & 39 & 21 & 24 \\
\hline Households with social grants (\%) & 83 & 75 & 74 & 76 & 84 & 70 \\
\hline Households with fridge (\%) & 72 & 94 & 96 & 75 & 85 & 89 \\
\hline Households with television (\%) & 68 & 96 & 93 & 75 & 83 & 71 \\
\hline $\begin{array}{l}\text { Average number of mobile phones per } \\
\text { household (\%) }\end{array}$ & 3.6 & n.d. & 3.8 & 3 & 3.7 & 3.1 \\
\hline Households ranked as poor (\%) & 54 & 37 & 55 & 36 & 60 & 40 \\
\hline
\end{tabular}

